DOI: $10.15290 /$ bsp.2020.25.02.17

Received: 10.05 .2020

Accepted: 16.06 .2020

\title{
Karolina Góralczyk
}

Uniwersytet w Białymstoku, Polska

e-mail: karolina93goralczyk@gmail.com

ORCID: https://orcid.org/0000-0001-7626-0501

\section{Glosa do wyroku Sądu Apelacyjnego w Krakowie z dnia 3 września 2015 r. (I ACa 679/15)}

\section{Wprowadzenie}

W wyroku z dnia 3 września 2015 r. ${ }^{1}$ Sąd Apelacyjny w Krakowie orzekł, że „Obiektywnie udostępnienie kolejnemu lekarzowi - profesorowi nauk medycznych - dokumentacji medycznej w celach konsultacyjnych, nawet z naruszeniem ustawy z 2008 r. o prawach pacjenta i Rzeczniku Praw Pacjenta², nie łączy się w powszechnym odczuciu z łamaniem tajemnicy lekarskiej w sposób godzący w dobra osobiste". Poruszona w orzeczeniu kwestia stanowi kanwę do dyskusji na temat tajemnicy dokumentacji medycznej oraz możliwości udostępnienia dokumentacji medycznej w celu sporządzenia prywatnej opinii biegłego w toku postępowania cywilnego.

\section{Stan faktyczny}

W glosowanej sprawie powódka dochodziła roszczeń z tytułu naruszenia dóbr osobistych w imieniu własnym jak i swojego małoletniego syna. Powódka pozwała

1 Wyrok Sądu Apelacyjnego w Krakowie z dnia 3 września 2015 r., sygn. I ACa 679/15, Lex nr 1927548.

2 Ustawa z dnia 6 listopada 2008 r. o prawach pacjenta i Rzeczniku Praw Pacjenta (tekst. jedn. Dz.U. z 2020 r. poz. 849), dalej: u.p.p. 
podmiot leczniczy za bezprawne udostępnienie dokumentacji medycznej. Dokumentacja medyczna została udostępniona przez pozwanego w czasie trwającego procesu o odszkodowanie i zadośćuczynienie z tytułu błędu medycznego celem sporządzenia opinii prywatnej, dotyczącej poprawności czynności medycznych wykonywanych przez personel medyczny wobec powódki w związku z jej ciążą. Powódka zarzuciła pozwanemu naruszenie jej prawa do prywatności, wskazując, iż nigdy nie wyrażała zgody na udostępnianie informacji medycznej obejmującej szczegółowe informacje o jej stanie zdrowia czy przebytych chorobach. W pozwie powołała się na przepisy art. 23 i 24 k.c. ${ }^{3}$ oraz ustawy z dnia 6 listopada 2008 r. o prawach pacjenta i Rzeczniku Praw Pacjenta, podając, iż dokumentacja pacjenta może być udostępniana jedynie w określonych przepisami przypadkach. Zarzuciła pozwanemu niedochowanie tajemnicy lekarskiej określonej przepisem art. 40 ustawy z dnia 5 grudnia 1996 r. $^{4}$ o zawodach lekarza i lekarza dentysty oraz naruszenie przepisów ustawy z dnia 29 sierpnia 1997 r. $^{5}$ o ochronie danych osobowych ${ }^{6}$. Powódka żądała w imieniu własnym i dziecka przeprosin $\mathrm{w}$ formie listu oraz zadośćuczynienia $\mathrm{z}$ tytułu naruszenia dóbr osobistych w kwocie $50000 \mathrm{zł} \mathrm{na} \mathrm{swoją} \mathrm{rzecz} \mathrm{i} 25000 \mathrm{zł} \mathrm{na} \mathrm{rzecz} \mathrm{małoletniego}$ powoda. Pozwany podmiot leczniczy wniósł o oddalenie powództwa oraz zasądzenie od strony powodowej kosztów procesu według norm przepisanych. Wskazał, że nie doszło do ujawnienia tajemnicy medycznej dotyczącej powodów.

Bezspornym w niniejszej sprawie pozostawało, iż pozwany podmiot leczniczy $\mathrm{w}$ toku innego procesu udostępnił dokumentację medyczną powódki oraz dokumenty z akt sprawy (pozew, pisma procesowe, odpowiedź na pozew, opinie biegłych) celem sporządzenia opinii prywatnej. Dokumentacja została udostępniona lekarzowi posiadającemu tytuł naukowy profesora. Pomimo iż pozwany szpital twierdził, że kopia dokumentacji medycznej nie zawierała widocznych danych pozwalających na identyfikację osób, to - jak ustalił sąd I instancji - podczas dokonywania anonimizacji pominięto czytelny podpis powódki pod badaniem posiewowym słuchu małoletniego powoda, niedokładnie zakreślono dane osobowe powódki - imię, nazwisko, pesel, adres zamieszkania, numer telefonu - oraz nazwisko powoda.

3 Ustawa z dnia 23 kwietnia 1964 r. - Kodeks cywilny (tekst. jedn. Dz.U. z 2019 r. poz. 1145).

4 Ustawa z dnia 5 grudnia 1996 r. o zawodach lekarza i lekarza dentysty (tekst. jedn. Dz.U. z 2020 r. poz. 514), dalej: u.z.l.

5 Ustawa z dnia 29 sierpnia 1997 r. o ochronie danych osobowych (tekst. jedn. Dz.U. z 2016 r. poz. 922), dalej: u.o.d.o.

6 Ustawa o ochronie danych osobowych z $1997 \mathrm{r}$. była podstawowym aktem prawnym w Polsce, który regulował problematykę ochrony danych osobowych. 25 maja 2018 r. ustawa o ochronie danych osobowych z 1997 r. została uchylona przez nową ustawę o ochronie danych osobowych z dnia 10 maja 2018 r. 25 maja 2018 r. zaczęło obowiązywać Rozporządzenia Parlamentu Europejskiego i Rady (UE) 2016/679 z dnia 27 kwietnia 2016 r. w sprawie ochrony osób fizycznych w związku z przetwarzaniem danych osobowych i w sprawie swobodnego przepływu takich danych oraz uchylenia dyrektywy 95/46/WE (tzw. RODO). 


\section{Stanowisko Sądu Apelacyjnego w Krakowie}

Sąd I instancji - Sąd Okręgowy uznał, że powództwo nie zasługiwało na uwzględnienie. Zdaniem sądu zgodnie $\mathrm{z}$ art. 27 ust. 2 pkt 5 u.o.d.o. do wyjątków od zasady zakazu przetwarzania danych osobowych należy zaliczyć sytuację, w której przetwarzanie dotyczy danych niezbędnych do dochodzenia praw przed sądem. Zakres materiałów przekazanych przez stronę pozwaną był uzasadniony treścią opinii, jaka miała zostać sporządzona, oraz był adekwatny do celu, jakiemu miała służyć opinia. Ponadto w uzasadnieniu orzeczenia Sąd Okręgowy podaje, iż pozwany udostępnił materiały jedynie w celu wydania opinii specjalistycznej celem wykorzystania jej w sprawie toczącej się między stronami. Działanie pozwanego zostało podjęte w obronie jego uzasadnionego interesu jako strony procesowej i jako takie nie było zadaniem bezprawnym. W tym wypadku, zdaniem sądu, udostępnienie dokumentacji medycznej służyło realizacji prawa do obrony pozwanego.

Sąd Apelacyjny wskazał, iż obiektywnie udostępnienie kolejnemu lekarzowi profesorowi nauk medycznych - dokumentacji medycznej w celach konsultacyjnych, nawet $\mathrm{z}$ naruszeniem ustawy o prawach pacjenta, nie łączy się w powszechnym odczuciu $\mathrm{z}$ łamaniem tajemnicy lekarskiej w sposób godzący w dobra osobiste. Ponadto sąd II instancji nie podzielił stanowiska sądu I instancji o wyłączeniu bezprawności, gdyż udostępnienie dokumentacji może nastąpić na mocy postanowienia sądu dopuszczającego dowód z opinii biegłego i tylko w tym celu może być wydana dokumentacja. Zdaniem sądu strona pozwana miała możliwość zgłoszenia wniosku o przeprowadzenie dowodu z opinii biegłego, jednak tego nie uczyniła, stąd udostępnienie dokumentacji lekarzowi stanowiło naruszenie praw pacjenta. Sąd II instancji stwierdził, że nie ma swobody w zakresie przetwarzania dokumentacji medycznej. Ponadto udostępnienie kolejnemu lekarzowi dokumentacji medycznej w celach konsultacyjnych stanowi o naruszeniu dóbr osobistych powodów. Sąd II instancji nie uwzględnił argumentu strony pozwanej, jakoby realizowała ona swoje własne prawo do obrony, ponieważ przedstawienie opinii prywatnej nie ma waloru dowodowego, a jedynie stanowi rozwinięcie własnych twierdzeń i zarzutów strony w prowadzonym procesie.

\section{Ocena stanowiska Sądu Apelacyjnego w Krakowie}

\section{1. Tajemnica dokumentacji medycznej}

Kluczowy dla rozwiązania problemu, z jakim zetknął się sąd, rozstrzygając niniejszą sprawę, był zakres obowiązywania tajemnicy medycznej, a jeszcze ściślej - tajemnicy dokumentacji medycznej. O istocie tajemnicy medycznej świadczy to, że jej fundamentem jest prawo do prywatności. Prawo do prywatności jest chronione konstytucyjnie zgodnie $\mathrm{z}$ art. 47 Konstytucji RP, który gwarantuje każdemu prawo do 
ochrony prawnej życia prywatnego, rodzinnego, czci i dobrego imienia oraz do decydowania o swoim życiu osobistym? ${ }^{7}$.

Prawo pacjenta do tajemnicy informacji z nim związanych zostało uregulowane w art. 13-14 ustawy o prawach pacjenta i Rzeczniku Praw Pacjenta. Zgodnie z art. 13 u.p.p.: „Pacjent ma prawo do zachowania w tajemnicy przez osoby wykonujące zawód medyczny, w tym udzielające mu świadczeń zdrowotnych, informacji z nim związanych, a uzyskanych w związku z wykonywaniem zawodu medycznego. Przepis ten reguluje prawo pacjenta do zachowania $\mathrm{w}$ dyskrecji wszystkich informacji, jakie zostaną powzięte przez osoby wykonujące zawody medyczne w związku z udzielanymi pacjentowi świadczeniami" ${ }^{\prime \prime}$. Prawo pacjenta do zachowania tajemnicy informacji z nim związanych jest skorelowane $\mathrm{z}$ obowiązkiem dochowania tajemnicy zawodowej przez osoby wykonujące zawody medyczne ${ }^{9}$. Jak wskazuje się w doktrynie, tajemnicą są objęte wszelkie fakty i informacje uzyskane przez podmioty udzielające świadczeń zdrowotnych, niezależnie od ich formy lub sposobu utrwalenia, zarówno informacje przekazywane w formie ustnej, jak również utrwalone w dokumentacji medycznej ${ }^{10}$.

Wszystkie osoby zatrudnione w podmiocie leczniczym zobowiązane są do zachowania $\mathrm{w}$ poufności informacji zawartych $\mathrm{w}$ dokumentacji medycznej prowadzonej przez ten podmiot ${ }^{11}$. To podmiot medyczny jest dysponentem dokumentacji medycznej. Tajemnica medyczna obejmuje wyniki przeprowadzonych badań, diagnozę postawioną na podstawie wyników, historię choroby i uprzednie postępowanie terapeutyczne, dokumentację medyczną, metody i postępy w leczeniu, wcześniejsze lub współistniejące schorzenia, hospitalizacje, przyjmowane leki, materiały związane z postawieniem diagnozy lub leczeniem. Ochronie podlegają wszystkie dane dotyczące osoby pacjenta. Podmioty medyczne są obowiązane dbać o zabezpieczenie miejsc przechowywania dokumentacji medycznej ${ }^{12}$. Tajemnica dokumentacji medycznej nie została uregulowana wprost, jednakże regulacje, które jej dotyczą, wywodzimy z przepisów ogólnych dotyczących tajemnicy medycznej zawartych m.in. w ustawie o prawach pacjenta i Rzeczniku Praw Pacjenta czy ustawie o zawodach lekarza i lekarza dentysty.

7 R. Kubiak, (w:) L. Bosek, Ustawa o prawach pacjenta i Rzeczniku Praw Pacjenta. Komentarz, Warszawa 2020, Komentarz do art. 13 u.p.p., Legalis; wyd. elektroniczne (22.04.2020).

8 G. Rejman, Tajemnica lekarska, „Studia Iuridica” 1996, nr 31, s. 187; S. Mikołajczak, Prawa pacjenta, Poznań 1994, s. 16.

9 Szerzej na temat obowiązku zachowania tajemnicy lekarskiej zob. R. Kubiak, (w:) E. Zielińska (red.), System prawa medycznego. Pojęcie, źródła, i zakres prawa medycznego, t. I, Warszawa 2018, s. 187-189.

10 Karkowska D., Ustawa o prawach pacjenta i Rzeczniku Praw Pacjenta. Komentarz, komentarz do art. 13 u.p.p., Warszawa 2016, Lex, wyd. elektroniczne (22.04.2020).

11 Ibidem.

12 D. Karkowska, Prawa pacjenta, rozdz. Prawo do domagania się zachowania poufności. Lex, wyd. elektroniczne (22.04.2020). 
Przenosząc powyższe rozważania na kanwę niniejszej sprawy, należy stwierdzić, iż tajemnica medyczna dotyczy również informacji zawartych w dokumentacji medycznej załączonej do akt postępowania cywilnego. Moment skierowania sprawy na drogę sądową nie zwalnia $\mathrm{z}$ zachowania tajemnicy ani nie rozszerza kręgu osób uprawnionych do informacji. Materialnym wyrazem powyższego twierdzenia jest to, że pomimo ograniczenia dostępu do akt sądowych tylko do osób upoważnionych, to dokumentacja medyczna bardzo często przechowywana jest w odrębnych zamkniętych kopertach znajdujących się w aktach. Ponadto, jak wynika z praktyki, zapoznanie się z jej zawartością jest często każdorazowo odnotowywane.

\subsection{Udostępnienie dokumentacji medycznej do celów postępowania cywilnego}

Jak wprost wynika z przepisów, tajemnica medyczna nie ma charakteru bezwzględnego, podobnie tajemnica dokumentacji medycznej. W przepisach prawa medycznego wyodrębnia się wiele wyjątków będących dyspensą od jej zachowania. Jak wskazuje D. Karkowska oraz R. Kubiak, przypadki zwolnienia z tajemnicy medycznej, a nawet zobowiązania do jej ujawnienia, można podzielić na dwie grupy: gdy tajemnica zostaje uchylona $\mathrm{z}$ uwagi na interes pacjenta oraz $\mathrm{z}$ uwagi na to, że przekazanie informacji jest niezbędne dla ochrony ważnego interesu publicznego lub osób trzecich ${ }^{13}$. Jedną $\mathrm{z}$ takich dyspens od zachowania tajemnicy dokumentacji medycznej jest jej udostępnienie do celów postępowania cywilnego ${ }^{14}$. Nie jest to jednak dyspensa absolutna. W glosowanej sprawie doszło do ujawnienia tajemnicy medycznej na potrzeby postępowania cywilnego poprzez udostępnienie dokumentacji medycznej bez zarządzenia sądu prowadzącego sprawę, ale przez jedną ze stron, na potrzeby sporządzenia opinii prywatnej. Rozważenia wymaga, w jakim dokładnie celu może zostać udostępniona dokumentacja medyczna, w jakim zakresie oraz w jaki sposób? ${ }^{15}$

W doktrynie wskazuje się, iż dane zawarte w dokumentacji medycznej mogą mieć istotne znaczenie dla różnych instytucji i być wykorzystywane do prowadzenia postępowań prawnych (cywilnych, administracyjnych i karnych) ${ }^{16}$. Oceniając możliwość udostępnienia dokumentacji medycznej, należy patrzeć przez pryzmat, że w dokumentacji medycznej znajdują się informacje objęte dyskrecją oraz ochroną dotyczącą sensytywnych danych osobowych, dlatego dostęp do takich informacji powinien być limitowany ${ }^{17}$.

13 D. Karkowska, Ustawa..., op. cit., s. 202; R. Kubiak, Tajemnica medyczna, Warszawa 2015, s. 39.

14 Szerzej o wykorzystywaniu dokumentacji medycznej na potrzeby postępowania cywilnego; zob. R. Kubiak, Tajemnica..., op. cit., s. 237-241.

15 Szerzej o udostępnianiu dokumentacji medycznej sensu largo zob. W. Preiss, E. Zielińska (red.), System prawa medycznego. Pojęcie, źródła i zakres prawa medycznego, t. I, Warszawa 2018, s. 489-493.

16 Kubiak, Tajemnica..., op. cit., s. 200.

17 Ibidem, s. 200. 
Na datę orzekania w niniejszej sprawie obowiązywały uchylone aktualnie przepisy ustawy o ochronie danych osobowych. Zgodnie z obowiązującym wówczas art. 27 ust. 5 u.o.d.o.: dopuszczalne jest przetwarzanie danych, które są niezbędne do dochodzenia praw przed sądem. Jak wyjaśnia J. Barta, nie można sprzeciwić się przetwarzaniu wrażliwych danych osobowych w postępowaniu przed sądem, jeśli jest to niezbędne do dochodzenia praw ${ }^{18}$. Opinia prywatna może znacząco ułatwić rozstrzygnięcie sprawy, przedstawić nowe, nieznane, naukowe i merytoryczne argumenty. W komentowanym przepisie mowa o dochodzeniu praw „przed sądem”, które obejmuje postępowanie karne, cywilne, administracyjne. Określenie „dochodzenie praw” przed sądem należy rozumieć szeroko i odnosić do działań wszystkich stron procesowych; chodzi tu zarówno o występowanie z roszczeniami, z oskarżeniem, jak i o obronę praw. Jak wskazuje J. Barta, w świetle art. 27 ust. 2 pkt 5 u.o.d.o. uprawnione do przetwarzania danych osobowych są zarówno organ sądowy, jak i strona występująca w postępowaniu lub jej pełnomocnik, za przykład podaje, iż pełnomocnik powoda może być na mocy tego przepisu uprawniony do przetwarzania danych osobowych pozwanego ${ }^{19}$.

Na podstawie wykładni powyższych przepisów należy wskazać, iż generalnie udostępnienie dokumentacji medycznej do celów sporządzenia opinii prywatnej jest dozwolone, choć powinno się to odbywać w sposób kontrolowany, uważny, limitowany, należny tajemnicy medycznej. Niedopuszczalne jest udostępnianie dokumentacji medycznej bez kontroli celu udostępnienia i sposobu, w jaki zostaje przekazana dokumentacja, a to zdaje się czynić podmiot leczniczy w omawianej sprawie, o czym świadczy szereg nieprawidłowości w postępowaniu. Dane osobowe pacjentki i jej małoletniego dziecka nie zostały odpowiednio zanonimizowane, opiniującej udostępniono zarówno pełną dokumentację medyczną pacjentki, jak też dokumenty $\mathrm{z}$ akt sprawy.

Dokumentacja może więc zostać udostępniona celem sporządzenia opinii prywatnej, a przemawia za tym naczelny argument, iż poprzez ograniczenie tego prawa de facto ograniczamy podmiotowi leczniczemu prawo do obrony swoich praw. Podstawowy problem, który powoduje, że komentowane orzeczenie zasługuje na glosę krytyczną, wynika z faktu, iż Sąd Apelacyjny uznał, że udostępnienie kolejnemu lekarzowi dokumentacji medycznej w celach konsultacyjnych stanowi o naruszeniu dóbr osobistych powodów. W uzasadnieniu Sąd Apelacyjny wskazał, iż przepisy prawa medycznego mają pierwszeństwo przed przepisami u.o.d.o. i zupełnie odrzucił argument pozwanego, iż realizował on swoje prawo do obrony, tym samym sąd odrzu-

18 J. Barta, P. Fajgielski, R. Markiewicz, Ochrona danych osobowych. Komentarz, Warszawa 2015, komentarz do art. 27 u.o.d.o., Lex, wyd. elektroniczne (18.04.2020). 
cił obowiązującą w postępowaniu cywilnym zasadę „równości broni” ${ }^{20}$. Sąd zupełnie pominął, iż opinia prywatna jest dokumentem prywatnym, a rolą sądu jest wzięcie pod uwagę argumentacji w niej przedstawionej i skonfrontowanie jej z tą prezentowaną przez biegłego sądowego. Z glosowanego orzeczenia wynika, iż pacjent może skorzystać z opinii prywatnej, natomiast podmiot leczniczy nie ma takiego prawa.

Jak wskazał w uzasadnieniu Sąd Apelacyjny, w niniejszej sprawie nie doszło do wyłączenia bezprawności, ponieważ udostępnienie dokumentacji może nastąpić na mocy postanowienia sądu dopuszczającego dowód z opinii biegłego i tylko w tym celu może być wydana dokumentacja. Strona może wystąpić z tego typu wnioskiem dowodowym, nie ma zaś swobody w zakresie przetwarzania dokumentacji medycznej.

Zaznaczyć należy, iż Sąd Apelacyjny zupełnie pominął rolę, jaką pełni opinia prywatna na etapie postępowania sądowego, nie wziął pod uwagę, że jest często jedynym możliwym środkiem do udowodnienia przez stronę twierdzeń odmiennych od przedstawionych w niekorzystnej opinii biegłego powołanego przez sąd ${ }^{21}$. Zlecenie sporządzenia opinii prywatnej w sprawach medycznych jest często jedynym przeciwdowodem, który pozwala na rzetelną dyskusję z twierdzeniami strony przeciwnej. Ważny postulat w tej materii wysuwa U. Drozdowska, wskazując na potrzebę regulacji w ustawie procesowej zagadnień związanych z wykorzystaniem opinii prywatnej ${ }^{22}$.

Odmiennie w niniejszym postępowaniu orzekł sąd I instancji, uznając zasadę równości stron i wynikającą z niej zasadę równości broni, stwierdzając, iż pozwany udostępnił dokumentację medyczną w ściśle określony celu, jakim było wydanie opinii specjalistycznej celem wykorzystania jej w sprawie toczącej się między stronami. Działanie to zostało podjęte przez pozwanego w obronie uzasadnionego interesu jako strony procesowej i jako takie nie było działaniem bezprawnym. Zdaniem Sądu Okręgowego podmiot leczniczy był uprawniony w zakresie przetwarzania danych zawartych w dokumentacji medycznej. Sąd wskazał, że na pozwanym ciążył obowiązek wykazania, iż jego działanie nie było bezprawne i ten obowiązek został zrealizowany zgodnie z treścią art. 24 k.c.

\subsection{Dokumentacja medyczna jako dokument podlegający szczególnej ochronie}

Przyjęcie, że dokumentacja medyczna pacjentki mogła zostać udostępniona na potrzeby postępowania cywilnego, a mianowicie w celu sporządzenia opinii pry-

20 Szerzej U. Drozdowska, Dopuszczalność wykorzystania tzw. opinii prywatnych w cywilnych procesach medycznych - uwagi na tle prawa pacjenta do dokumentacji medycznej, „Białostockie Studia Prawnicze" 2017, vol. 22, nr 2, s. 131 i n.

21 Szerzej: ibidem, s. 124-129.

22 U. Drozdowska, Dopuszczalność..., op. cit., s. 134. 
watnej, nie determinuje wniosku, iż w niniejszej sprawie dokumentacja medyczna została udostępniona w sposób prawidłowy. Głównym problemem komentowanej sprawy jest nie okoliczność, czy dokumentacja mogła być legalnie udostępniona na potrzeby sporządzenia opinii prywatnej, ponieważ mając na względzie zasadę równości stron, obowiązujące wówczas przepisy u.o.d.o., było to możliwe, ale to, czy została udostępniona w sposób prawidłowy, z zachowaniem standardów należnych tajemnicy medycznej.

Na wstępie należy wskazać, iż dokumentacja medyczna ma szczególny status również dlatego, że zawiera dane medyczne uznawane za rodzaj danych wrażliwych, zgodnie z ustawą o ochronie danych osobowych. Jak wskazuje R. Kubiak, dane medyczne, a przez to dokumentację medyczną, zaliczamy do danych sensytywnych podlegających szczególnej ochronie ${ }^{23}$. Szczególna ochrona dokumentacji medycznej wynika więc z przepisów ustawy o prawach pacjenta i Rzeczniku Praw Pacjenta. Do tajemnicy dokumentacji medycznej winniśmy stosować tożsame reguły, jakie stosujemy wobec tajemnicy medycznej sensu largo.

W niniejszej sprawie podmiot leczniczy udostępnił dokumentację medyczną powódki oraz dokumenty z akt sprawy (pozew, pisma procesowe, odpowiedź na pozew, opinie biegłych) celem sporządzenia opinii prywatnej. Dokumentacja została udostępniona lekarzowi posiadającemu tytuł naukowy profesora. Podczas dokonywania anonimizacji pominięto czytelny podpis powódki pod badaniem posiewowym słuchu małoletniego powoda, niedokładnie zakreślono dane osobowe powódki - imię, nazwisko, pesel, adres zamieszkania, numer telefonu - oraz nazwisko powoda. Do takiego postępowania należy odnieść się w sposób krytyczny.

Aby zapewnić ochronę tajemnicy medycznej zawartej w niniejszej dokumentacji pozwany winien bezbłędnie zanonimizować przekazywaną do opinii dokumentację, gdyż do jej sporządzenia nie były potrzebne dane osobowe pacjentki. W niniejszej sprawie tego nie uczyniono, jak stwierdził sąd I instancji, dane osobowe oraz inne dane pozwalające na identyfikację powódki oraz urodzonego przez nią dziecka zostały zakreślone w ten sposób, aby były nieczytelne, jednakże podczas dokonywania anonimizacji pominięto czytelny podpis powódki pod badaniem posiewowym słuchu małoletniego powoda, a nadto niedokładnie zakreślono inne dane osobowe powódki. Należy krytycznie odnieść się do opinii wyrażonej w niniejszej sprawie przez sąd I instancji, jakoby jedynie niewielka część danych osobowych powódki omyłkowo została pominięta, a część pomimo zakreślenia pozwalała na identyfikację powódki i jej dziecka. Podkreślenia wymaga fakt, iż jeden błąd przy anonimizacji dokumentacji medycznej, pominięcie pojedynczych danych powoduje, że de facto dane pacjenta w ogóle nie są zanonimizowane. Celem anonimizacji jest uniemożliwienie przyporządkowania poszczególnych informacji do określonej lub możliwej do ziden- 
tyfikowania osoby fizycznej, a więc pomięcie choćby nawet niewielkiej części danych powoduje, że tożsamość pacjenta jest znana.

Powyższe jest jedną z kluczowych kwestii w niniejszej sprawie, gdyż zarówno sąd I jak i sąd II instancji przyznał, iż udostępnienie dokumentacji medycznej wymagało anonimizacji, która w tym przypadku była nieprawidłowa. Nie sposób jednak zgodzić się z Sądem Apelacyjnym, iż „wprawdzie wadliwie dokonano przy tym anonimizacji, jednakże informacje, objęte dokumentacją medyczną zawierające dane osobowe i objęte tajemnicą lekarską, zostały udostępnione bez ryzyka szerokiego rozpowszechnienia. Natomiast niedbalstwo pracowników, za których odpowiada pozwana, było niewielkie”. Należy zaznaczyć, iż w niniejszym stanie faktycznym nie powinno mieć znaczenia, czy dane nie zostały zanonimizowane na jednym, czy na kilku dokumentach. Przyjąć należy, że nawet jedno zaniechanie $\mathrm{w}$ anonimizacji danych na dokumentacji medycznej pacjenta powoduje, iż dane te nie zostały prawidłowo zabezpieczone.

Należy również rozważyć czy znaczenie w niniejszej sprawie ma okoliczność, jakiemu podmiotowi udostępniono dokumentację medyczną celem sporządzenia opinii. Jak wielokrotnie podkreśla sąd II instancji, dokumentacja medyczna została udostępniona innemu lekarzowi - profesorowi nauk medycznych, a pomimo że opiniujący lekarz nie był w niniejszym stanie faktycznym pracownikiem pozwanego, to z uwagi na wykonywany zawód lekarza był zobowiązanych do zachowania tajemnicy informacji związanych z pacjentem z uwagi na ustawowy obowiązek wynikający z art. 40 u.z.l. Nie sposób się zgodzić z przyjętą przez sąd II instancji interpretacją, iż obiektywnie udostępnienie kolejnemu lekarzowi - profesorowi nauk medycznych - dokumentacji medycznej w celach konsultacyjnych, nawet z naruszeniem ustawy o prawach pacjenta, nie łączy się w powszechnym odczuciu z łamaniem tajemnicy lekarskiej w sposób godzący w dobra osobiste.

Okoliczność, iż poszczególne zawody medyczne - zawód lekarza, pielęgniarki itd. - są związane tajemnicami zawodowymi, nie pozwala na przyjęcie, że wszystkim osobom zobowiązanym do zachowania tajemnicy medycznej można udostępniać dokumentację medyczną, a do tego właściwie prowadzi argumentacja forsowana w uzasadnieniu glosowanego orzeczenia. Ponadto w doktrynie wielokrotnie próbowano dokonać wyszczególnienia sytuacji, w których tajemnica medyczna może zostać ujawniona innym pracownikom medycznym. Jako kryterium główne ujawnienia danych dyskretnych wskazywany jest cel, w jakim tajemnica ma być naruszona - potrzeba udzielenia świadczeń zdrowotnych choremu ${ }^{24}$. Samo wykonywanie zawodu medycznego nie predysponuje do ujawnienia dyskrecji medycznej, a za takim argumentem niejako obstaje sąd w swym uzasadnieniu. Okolicznością łagodzącą w niniejszej sprawie nie jest więc fakt, że dokumentacja została udostępniona innemu 
lekarzowi, gdyż nie było to związane z naczelnym celem, który niejako legalizuje pola ujawniania dokumentacji medycznej.

Nie do przyjęcia jest stwierdzenie Sądu Apelacyjnego, iż sama okoliczność, że profesor nauk medycznych, będący znanym i powszechnie uznanym lekarzem o specjalizacji ginekologia-położnictwo i do tego będący kobietą, dowiedział się o fakcie i przebiegu powikłanego porodu i jego skutkach dla zdrowia powodów, w obiektywnej ocenie społecznej nie będzie godziła w stan uczuć i w ramach tej oceny nie będzie uznawana za ingerencję w sferę prywatności, w sytuacji świadomości, że informacje o porodzie i jego powikłaniach były przedmiotem wiedzy wielu pracowników służby zdrowia, co więcej - były przedmiotem oceny sądu w procesie $\mathrm{z}$ woli samych powodów. Z powyższą argumentacją nie sposób się zgodzić, gdyż dla stwierdzenia naruszenia tajemnicy medycznej nie ma znaczenia okoliczność płci osoby naruszającej czy jej tytuł naukowy. Tytułem uzupełnienia dodać należy, iż w niniejszej sprawie nie mieliśmy do czynienia z ujawnieniem dokumentacji medycznej biegłemu sądowemu ani przekazaniu danych w celu naukowo-dydaktycznym.

$\mathrm{Na}$ koniec należy podjąć refleksję nad zakresem dokumentacji medycznej, ale też dokumentacji procesowej, która może być udostępniona w toku toczącego się postępowania. W niniejszej sprawie celem sporządzenia opinii przekazano zarówno dokumentację medyczną pacjentki, jak i dokumentację sądową. Czy konieczne było udostępnianie opiniującej również dokumentacji sądowej? Wystarczające byłoby zadanie pytań opiniującej i udostępnienie w pełni zanonimizowanej dokumentacji medycznej. Na potrzeby tego procesu zapewne konieczne było udostępnienie pełnej dokumentacji medycznej, co pozwoliło sprawdzić, czy wszystkie świadczenia medyczne były wykonane w sposób prawidłowy. Przy udostępnianiu dokumentacji medycznej, co do zasady jednak, zastosowanie znajduje zasada minimalizmu, zgodnie z którą zakres informacji powinien być ściśle związany z zakresem opiniowanych czynności. W doktrynie zasadę minimalizmu stosuje się do informacji przekazywanych o pacjencie celem udzielania mu dalszych świadczeń zdrowotnych, informacja ma charakter limitowany, jej zakres jest ustalany w oparciu o to, jakie dane będą konieczne do kontynuowania udzielania świadczeń zdrowotnych w sposób prawi$\mathrm{dłowy}^{25}$. Skoro więc wskazana zasada ma zastosowanie w stosunku do informacji przekazywanych w stosunku do udzielania świadczeń zdrowotnych, powinna również być stosowana do udostępniania dokumentacji w celu sporządzenia ekspertyzy.

Zaznaczyć należy, iż bez wątpienia strona powodowa powinna zostać poinformowana o udostępnieniu jej dokumentacji medycznej do celu sporządzenia prywatnej opinii lekarskiej przez podmiot leczniczy. Podobne zalecenia czyni się w odniesieniu do udostępniania danych pacjenta do celów naukowo-dydaktycznych. Uznanie zasady „równości broni” nie zwalnia, w mojej ocenie, podmiotu leczniczego od poinformowania pacjenta o uchyleniu tajemnicy $\mathrm{w}$ stosunku do danych doku- 
mentów celem sporządzenia opinii prywatnej na potrzeby toczącej się sprawy, gdyż w związku z taką działalnością może dojść do naruszenia sfery prywatnej pacjenta. Z uwagi na wątpliwości, jakie budzi cel udostępnienia dokumentacji medycznej do opinii prywatnej, tym bardziej takie udostępnienie zawsze powinno być poprzedzone poinformowaniem zainteresowanego ${ }^{26}$.

\section{Wnioski}

Należy wskazać, iż osią sporu w niniejszej sprawie jest to, że przeciwstawiane są sobie dwa interesy. Z jednej strony interesy procesowe - potrzeba udowodnienia prawidłowości leczenia przez podmiot leczniczy, natomiast z drugiej interes i prywatność pacjenta - potrzeba i prawo zachowania w tajemnicy informacji dotyczących stanu zdrowia pacjentki i jej małoletniego dziecka ${ }^{27}$. Obydwa te interesy można pogodzić, o ile w sposób prawidłowy zostaną zastosowane narzędzia do anonimizacji dokumentacji medycznej. Dokumentacja medyczna jest objęta tajemnicą medyczną i powinien mieć wobec niej zastosowanie najwyższy standard. Można wysnuć wniosek, iż zaistniała sytuacja zostałaby odmiennie oceniona przez powódkę, gdyby została ona poinformowana o udostępnieniu dokumentacji medycznej na potrzeby opinii prywatnej, gdyby udostępniona dokumentacja została odpowiednio zanonimizowana.

Sąd Apelacyjny w glosowanym orzeczeniu błędnie afirmuje rozumienie tajemnicy dokumentacji medycznej, forsując tezę, iż udostępnienie dokumentacji opiniującemu lekarzowi stanowiło naruszenie praw pacjenta. Tymczasem akcent powinien zostać położny na to, że w komentowanej sprawie sam proces udostępnienia dokumentacji był nieprawidłowy. Wówczas zostałby osiągnięty kompromis pozwalający jednej ze stron zapewnić maksymalną ochronę praw pacjenta, natomiast drugiej umożliwić prawo do obrony.

\section{BIBLIOGRAFIA}

Barta J., Fajgielski P., Markiewicz R., Ochrona danych osobowych. Komentarz, Warszawa 2015, Lex, wyd. elektroniczne.

Górski A., Leksykon prawa medycznego. 100 podstawowych pojęć, Warszawa 2012.

Drozdowska U., Dopuszczalność wykorzystania tzw. opinii prywatnych w cywilnych procesach medycznych - uwagi na tle prawa pacjenta do dokumentacji medycznej, „Białostockie Studia Prawnicze" 2017, vol. 22, nr 2.

Karkowska D., Prawa pacjenta, Lex, wyd. elektroniczne.

26 Ibidem, s. 77.

27 A. Górski, Leksykon prawa medycznego. 100 podstawowych pojęć, Warszawa 2012, s. 231. 


\section{Karolina Góralczyk}

Karkowska D., Ustawa o prawach pacjenta i Rzeczniku Praw Pacjenta. Komentarz, Warszawa 2016, Lex, wyd. elektroniczne.

Kubiak R., Prawo medyczne, Warszawa 2014.

Kubiak R., Tajemnica medyczna, Warszawa 2015.

Kubiak R., (w:) E. Zielińska (red.), System prawa medycznego. Pojęcie, źródła i zakres prawa medycznego, t. I, Warszawa 2018.

Kubiak R., (w:) Bosek L., Ustawa o prawach pacjenta i Rzeczniku Praw Pacjenta. Komentarz, Warszawa 2020, Legalis; wyd. elektroniczne.

Mikołajczak S., Prawa pacjenta, Poznań 1994.

Preiss W., (w:) E. Zielińska (red.), System prawa medycznego. Pojęcie, źródła i zakres prawa medycznego, t. I, Warszawa 2018.

Rejman G., Tajemnica lekarska, „Studia Iuridica” 1996, nr 31. 